\section{Regards sur l'économie allemande}

Bulletin économique du CIRAC

$68 \mid 2004$

Varia

\title{
Droit public
}

BENZ Arthur et al. (ed.), Institutionenwandel in Regierung und

Verwaltung. Festschrift für Klaus König zum 70. Geburtstag

\section{OpenEdition}

\section{Journals}

Édition électronique

URL : http://journals.openedition.org/rea/3639

DOI : $10.4000 /$ rea.3639

ISBN : 978-2-8218-0832-4

ISSN : 1965-0787

Éditeur

CIRAC

Édition imprimée

Date de publication : 1 octobre 2004

ISSN : 1156-8992

Référence électronique

«Droit public », Regards sur l'économie allemande [En ligne], 68 | octobre 2004, mis en ligne le 29 avril 2009, consulté le 22 septembre 2020. URL : http://journals.openedition.org/rea/3639 ; DOI : https:// doi.org/10.4000/rea.3639

Ce document a été généré automatiquement le 22 septembre 2020

(C) CIRAC 


\section{Droit public}

BENZ Arthur et al. (ed.), Institutionenwandel in Regierung und

Verwaltung. Festschrift für Klaus König zum 70. Geburtstag

\section{RÉFÉRENCE}

BENZ Arthur et al. (ed.), Institutionenwandel in Regierung und Verwaltung.

Festschrift für Klaus König zum 70. Geburtstag, Coll. Schriften zum öffentlichen

Recht, vol. 950, Duncker \& Humblot, Berlin, 2004, 756 p.

1 Les contributions internationales rassemblées dans cet ouvrage collectif éclairent les diverses facettes du droit public et administratif allemand, français, britannique ou américain. Au centre des approches : l'état de la recherche sur le droit des institutions, l'évolution des missions publiques, les implications de l'intégration européenne sur le processus de transformation institutionnelle des nouveaux Etats membres, ainsi que la question de l'intégration politique de l'UE. (ib) 